\title{
Equity as a Basis for Inclusive Educational Systems Change
}

\author{
Wayne Sailor, Ph.D. \\ University of Kansas \\ SWIFT Center \\ Word Count: 8,812
}

\begin{abstract}
Inclusion of students with “disabilities” in public systems of general education has been a global initiative since the Salamanca Statement and Framework for Action by the UN General Assembly in 1994. Despite global and national policy efforts the practice has been sporadic and elusive. Framing education as categorical, specialized service delivery to discrete populations makes inclusion an unsolvable problem. The advent of multi-tiered systems of support (MTSS) coupled with universal design for learning (UDL) practices delivered in whole-school rather than classroom-based formats poses a pathway out of the conundrum by framing public education as a system of equitable distribution of resources such as services and supports based on measured and monitored need on the part of all students. Potentially supportive research literature is reviewed.
\end{abstract}

Key Words: EQUITY; INCLUSION; MULTI-TIERED SYSTEM OF SUPPORT; SYSTEMS CHANGE, UNIVERSAL DESIGN FOR LEARNING

SWIFT Center produced the data for this paper under U.S. Department of Education, Office of Special Education Programs Grant No. H326Y120005. OSEP Project Officers Grace Zamora Durán and Tina Diamond served as the project officers. The views expressed herein do not necessarily represent the positions or policies of the Department of Education. No official endorsement by the U.S. Department of Education of any product, commodity, service or enterprise mentioned in this publication is intended or should be inferred. 


\section{Equity as a Basis for Inclusive Education Systems Change}

Rittel and Webber (1973) wrote "The search for scientific bases for confronting problems of social policy is bound to fail, because of the nature of these problems. They are 'wicked' problems, whereas science has developed to deal with 'tame problems'” (p. 155). The social professions (e.g., education) have evolved as conduits for application of scientific knowledge from their respective disciplines (e.g., psychology). As such, they assume responsibility for planning functions and guidance in formulation of social policy. Yet the relationship of knowledge production (science) to applications (profession) breaks down in the face of wicked problems. A problem is wicked, in Rittel and Webber's terms, when its solution is bound up in its formulation and the context of the problem militates against its formulation. Within different professional groupings are people with different values, epistemological preferences, and so on, and solutions for social policy problems become caught up in the conflicts among them. Knowledge production proceeds apace in support of all solutions until one prevails. New solutions to old wicked problems may result in the overthrow of prevalent paradigms (Kuhn, 1970; Skrtic, 1993).

"Inclusion” of students with “disabilities” in general education arrangements fits the definition of a wicked problem. The significance of this problem rests in the current values underpinning a large slice of international social policy in education, which appear to be largely driven by the Salamanca Statement and Framework for Action (United Nations General Assembly, 1994). The Salamanca Framework emerged in response to earlier social policy guidelines for "special” education that failed to adequately address the issue of inclusion (Ainscow \& Cesar, 2006; McMaster, 2013). This Framework calls for all students to be educated in inclusive schools by 2015. That year has now receded into history and the wicked 
problem of inclusion remains unsolved as exemplified by its continued relative absence in schools worldwide (Brock \& Schaefer, 2015; Kurth, Morningstar, \& Kozleski, 2014; Smith, 2007).

In this paper my aim is to propose a solution to the problem of inclusion, one that already has some acceptance within public education, but has yet to emerge as a coherent framework for professional practice. The reader has probably noted that I am putting quotes around some commonly accepted terms (i.e., “disability”, “inclusion”, “special”). I do this because the solution I propose calls for reframing the problem (Bolman \& Deal, 2013; Deal \& Peterson, 2009). These three terms lose their commonly understood meanings under the context of the reframed problem.

\section{Epistemology}

Reframing the problem of inclusion requires consideration of the means by which the scientific disciplines inform the profession of education. In education one can discern the contributions primarily of four disciplines: biology (mediated through the profession of medicine), sociology, anthropology, and psychology. Of these, the dominant paradigm is contributed through psychology, the science of the individual human. This dominant paradigm holds that disability is a property of individuals and, as such, can be likened to a quasi-disease state (Bogdan \& Kugelmass, 1984; Skrtic, 1993). As a biological property of individuals, disability can be addressed through scientific knowledge (positivism) in the manner of medicine, namely diagnosis and prescriptive cure or prosthesis (Schön, 1984).

By the logic of post-positivism (e.g., Sailor \& Paul, 2004), children afflicted with disability can benefit from the transfer of scientific knowledge into the profession of education through a sub-branch of the profession called special education. The term "special” in this 
context appears to be a somewhat euphemistic characterization of the recipients as "special" children. Thus, as Skrtic (1993) points out, the dominant paradigm of psychology in partnership with medicine, "place the root cause of deviance within the person, and exclude from consideration causal factors that lie in the larger social and political processes external to the individual”. (p. 170).

Further, the post-positivist paradigm logically points to a need for highly specialized teachers specifically trained in the various disability categories, a need for a specialized curriculum in many cases (e.g., "life skills"), and special classrooms or entire schools set aside to provide the special education. As Skrtic (1993) puts it,

Real progress in special education will require a different frame of reference. At a minimum, it will require that special education take seriously the critics of its theoretical and applied knowledge, and thus of its taken-for-granted assumptions. It will require criticism in the classical sense-self-reflective examination of the limits and validity of special education knowledge. But the problem is that the professional community of special education will not readily accept theoretical criticism, precisely because it contradicts the field's taken-for-granted assumptions about the nature of disability, diagnosis, special education, and progress. (p.171)

Slee and Allan (2001) advanced a similar view writing from the perspective of critical theory. Citing Hall and Jacques (1989), they argued that the values underlying policy directives favoring inclusion have been subverted, from an emancipatory project to a conservative one driven by the dominant epistemology of positivism within special education. From a critical theory perspective, the construct of inclusion gets caught up in the politics of special education 
(Barton, 1987). With the post-World War II shift in the U.S., for example, from a manufacturing economy to a service economy (McKnight, 1995), special education can be seen as a promising “market maker”. Witness, for example, the expansion of the label “autism”, from a distinct pathological syndrome three decades ago, to “autism spectrum disorder” now, with new subcategories of diagnostic tools, specialized professionals, and unique teaching/learning configurations. In Australia, for example, the adoption of the individualized educational program (IEP) from the U.S. Individuals with Disabilities Education Act (IDEA) may be seen as a driver for the expansion of students identified for special education from $2.6 \%$ in 1998 to $4.8 \%$ in 2009 (Dempsey, 2012). The ever expanding categorical specialization within special education poses a direct challenge to inclusive, more sociologically-driven systems of support within education and, as such, is strongly resisted by post-positivist special educators (e.g., Fox \& Ysseldyke, 1997; Kauffman, McGee, \& Brigham, 2004; Kauffman \& Hallahan, 1995). On the other hand, there are encouraging signs of growing discontent with the unreliability of special education diagnostic categories (McLaughlin, Snyder, \& Algina, 2015).

\section{Reframing Education as an Alternative to "Inclusion"}

Perhaps the problem of inclusion is indeed bound up in its definition. Two distinctly different definitions can be discerned from the literature. The dominant, prevailing definition is consistent with post-positivist special education and is placement-based. Should we re-place students who have been assigned to a special education classroom, instead into a general education classroom (grade-level or content) (McLeskey, Waldron, Spooner, \& Algozzine, 2014, p. i)? Arguments against this approach are prolific in the anti-inclusion literature-general education teachers not trained to handle disability; requires paraprofessionals; may be disruptive 
to "non-disabled” students; deprives disabled students from needed specialized services and shelter; may compromise test scores under conditions of high-stakes assessment; etc.

From a more sociological, constructivist position Artiles and Kozleski (2007; 2016) have advanced a definition that shifts concern away from physical space and toward a conception of equity, the distribution of available evidence-based supports and services to students who need them to successfully engage the teaching/learning process, regardless of the nature of the problem. This definition applies to all students and helps us to move away from strict reliance on the medical model of "disability". Further it shifts emphasis away from the classroom as the unit of analysis, and toward whole-school applications (Booth \& Ainscow, 2011; McMaster, 2013; Sailor, 2009; Sailor \& Burrello, 2013).

Addressing the problem of inclusion through reframing the broader problem of educating all children by shifting away from post-positivist epistemology and toward a more sociological, constructivist project would seem to bring us more into alignment with the U.K. and away from the U.S. and other European approaches (Mintz \& Wyse, 2015). These authors argue "there has never been any established tradition of specialist education . . . at least in initial teacher training in the U.K.” (p. 1165). Further, “In England, teacher training institutions have been strongly influenced by Lewis and Norwich’s (2005) argument that there is no such thing as a special needs pedagogy” (p. 1165). Mintz and Wyse conclude their critique of special education with what I would interpret as a call to pragmatism (e.g., Rorty, 1989): “such a pedagogy is likely to be more effective if it includes an openness to investigating what psychology may have to tell us about those individual needs, which will include particular pedagogic strategies specific to particular diagnostic groups” (p. 1168). In other words, to go whole-hog postmodern (Lewis \& Norwich, 2005; Slee \& Allan, 2001) and reject instrumentalism’s contribution to education 
entirely would be to "throw the baby out with the bathwater." Real value exists in scientific

knowledge applied to categories of learning problems (e.g., learning disabilities, autism, etc.).

\section{Is Inclusion a Pathway to Reframing Education?}

Writing from the perspective of a need for broader teacher preparation curricula and praxis, Kozleski and Siuty (2016) wrote

Inclusive education is an educational agenda that, in its ideal form, can transform educational policies, structures and agencies. Its implementation demands new patterns and routines in what counts as education, the delivery of opportunities to learn and the forms and processes of student participation. ...In our view, an inclusive education agenda calls for seismic shifts in how teachers are socialized into the profession, including a curriculum that encompasses critical, contextual and technical knowledge in application. We also advance the notion that teacher education must be a transformative venture in which teacher candidates reframe and renegotiate their own identities as they prepare to teach students whose cultural histories, practices and values may challenge the dominant notion of schooling. (p.1).

Their view of replacing placement-based definitions of inclusion with a whole-school equity grounded frame can serve as a catalyst for de-marginalizing all educational victims of subgrouping.

Similarly, Burrello, Sailor, and Kleinhammer-Tramill (2013) argued for a shift to the same ends, from a human capital agenda for education to a human capabilities agenda. Looking at U.S. policy, for example, Burrello et al. (2013) wrote 
While No Child Left Behind (NCLB) was publicly presented as a renewed effort to achieve equity, Apple (2006) and others have critiqued what they perceive as a neoliberal agenda with a feverish commitment to markets, privatization, and commodification of education. Apple feared the hidden implications of this movement are only slowly emerging, which could lead to a separate system of private and public charters serving students with disabilities in separate, segregated settings. Moreover, current discussions of reauthorization of the ESEA (e.g., U.S. Department of Education, 2010) have reemphasized the link between education and employment. (p.6).

\section{Does Inclusion Produce Better Outcomes for Students?}

The question of better student outcomes through inclusion continues to be a thorny and hotly contested issue (Farrell, Dyson, Polat, Hutcheson, \& Gallannaugh, 2007; Fuchs et al., 2014; Lyons \& Cassebohm, 2012; McClesky, Landers, Williamson, \& Hoppey, 2012). In the current U.S. political climate, a reframing of educational praxis will be unlikely to advance on the basis of a human rights agenda. Although an equity definition of inclusion is consistent with the U.S. Constitution and Bill of Rights, and thus constitutes expressed American societal values in terms of philosophical pragmatism, policy makers are more likely to be swayed in their leanings on the basis of scientific evidence indicating that new practices should replace the old. While there is scant literature on longitudinal outcomes accruing to inclusion vs. segregation for schooling (see Brown, Shiraga, \& Kessler, 2006 for an exception) there is a rapidly growing body of evidence for better academic and social measured outcomes for students identified for special education during the schooling years (Browder, Hudson, \& Wood, 2014; Courtade, Jimenez, \& Delano, 2014; Causton \& Theoharis, 2014; Florian \& Rouse, 2014; Jackson, 
Ryndak, \& Wehmeyer, 2010; Kleinert et al., 2015; McDonnell, Thorson, Disher, MathotBuckner, Mendel, \& Ray, 2003; Nota, Soresi \& Ferrari, 2014; Oh-Young \& Filler, 2015;

Peetsma, Vergeer, Roeleveld, \& Karsten, 2001).

Each of the references cited above contains reviews of published research investigations favoring outcomes associated with inclusive education. The weighty preponderance of these studies is persuasive, although the issue of the translation of these studies into classroom and schoolwide practices remains challenging (Grima-Farrell, Bain, \& McDonagh, 2011). Nevertheless, a justifiable warrant is clearly at hand to advance a global social policy agenda to de-segregate public education settings and reframe education as a coherent and holistic project with equitable distribution of available evidence-based resources and supports directed to all students on the basis of their measured needs rather than on assumptions about who they are (Sailor \& McCart, 2014).

\section{Emerging Characteristics of Equity-Based Inclusive Education}

Thus far, I have proposed that inclusion is a "wicked” problem that can only be understood in terms of its solution, which has not occurred to date and cannot occur under the present frame of global educational structure and praxis. I advanced the thesis that shifting to a different conceptualization of inclusion grounded in a reframing of public education, with equitable distribution of resources as its basis, points the way to a solution that applies to all students. Next I review recent literature addressed to the issue of what equity-based inclusive education looks like in practice and then conclude with a conceptual model for schooling grounded in a multi-tiered system of distributing equitable resources across all students. 


\section{Structural Elements}

If all students, no matter the range and intensity of their needs for support to engage the general curriculum, are to be educated alongside their peers—some of whom require extraordinary services or supports—what should such a school look like? Should the grade-level (or content) classroom be the unit of analysis? Should paraprofessionals (teaching assistants) be a part of the picture, and if so, how should they be deployed and what should be their role? How should the school maximize the use of such specialized resources as special education, gifted, second language instruction, health care, and other ancillary professional resources including parents, and indeed, the students themselves?

Most approaches to structuring inclusive schools in such a way as to accommodate students with more extensive support needs (i.e., "severe disabilities") follow a placement-based conception of inclusion, which makes the general education classroom the unit of analysis. Whole-school structural conceptions are just beginning to emerge (McLeskey et al., 2012; Booth \& Ainscow, 2011; Sailor \& Burrello, 2013). Research indicates that inclusive education benefits students identified for special education academically and socially, the latter by promoting interactions with ("non-disabled”) peers. Yet the preponderance of these investigations have focused on students requiring less extensive supports (i.e., “mild, moderate disabilities”).

Feldman, Carter, Asmus, and Brock (2016) reported a study of 108 high-support-need high school students included in general education classrooms. In conducting some 423 fullclass-length observations they concluded that high-support-need students often failed to stay in class for the whole period and when present were often not in proximity to peers. They also reported a disproportionate degree of absenteeism compared to their general education peers. 
Findings such as these illustrate the problem with placement-based definitions of inclusion. Simple location is insufficient to realize academic and social gains.

Giangreco and Suter (2015) offered a structural arrangement that more closely fits an equity-based frame for school organization. Emphasizing a whole school as the unit of analysis, they illustrated how a multi-tiered system of support (MTSS) for all students can provide a driver for organizing available school personnel (i.e., teachers, therapists, administrators, paraprofessionals) in configurations through master scheduling that can enhance social and academic outcomes for all students including those with high support needs. Burrello et al. (2013) advanced a similar call for a unified structural approach to schooling grounded in MTSS (with embedded response to intervention-RTI) as a basis for deploying special education resources.

\section{Administrative Elements}

Research has consistently shown that school leadership is a powerful predictor of student achievement (Di Paolo \& Walther-Thomas, 2003; Fullan, 2004; Klingner, Arguelles, Hughes, \& Vaughn, 2001; McLeskey et al., 2014). Di Paola, Tschannen-Moran, and Walther-Thomas (2004) reviewed the literature on leadership and its impact within the context of school organizational change from hierarchical models to more democratically organized, team-driven structures associated with inclusive education. They found that the democratic models built on collaboration and organizational citizenship were more efficient. Principals in these schools improved school climate by building a culture of trust, which affects student achievement, possibly by improving teacher morale (Tschannen-Moran, 2004).

Recent organizational shifts in U.S. higher administrative units, such as school districts (local educational agencies or LEAs and state education agencies or SEAs), responding to a 
results-driven accountability initiative at the federal level (U.S. Department of Education, 2016), are showing promise for alignment of systems and coherence in various program areas using implementation science (National Center for Systemic Improvement, 2013). States that are currently in partnership with the SWIFT Center (a federally funded inclusive school reform technical assistance system), for example, are aligning all systems from state planning to school teams to achieve measurable student outcomes for all students (Schoolwide Integrated Framework for Transformation Center, 2016).

\section{Implications for Teachers}

The disability construct and its categorical service delivery systems under special education poses challenges for school organizational initiatives promoting inclusive education within a human capabilities frame (Burrello et al., 2013). General educators, who are used to referring difficult-to-teach students elsewhere to be served by specialists, have trouble imagining educating those students for whom their training has left them feeling poorly equipped.

Similarly, special educators are likely to feel disconnected from the general education curriculum and to feel a sense of ownership and protectiveness toward students placed in special education.

Morris and Sharma (2011), for example, employed focus group methodology to examine provision of educational services and supports to students with blindness in inclusive settings. They found that parents, teachers, and paraprofessionals tended to perform tasks for blind students, thus reducing their autonomy and progress toward greater independent functioning. They concluded that itinerant services provided for vision need to provide training to parents and school staff in addition to students.

Similarly, in South Africa, Walton (2011) reported that learners with academic difficulties in inclusive settings were shunted away from taking the matric, the external 
examination undertaken by students at grade 12 to determine eligibility for further education. They concluded that teachers need to receive training, not only in inclusive practices, but also to question their beliefs and value systems concerning student worth. They agreed that a key to changing attitudes of teachers in South Africa is to promote greater parent involvement in the schools.

Hemmings and Woodcock (2011) employed survey research methodology to explore readiness to teach in inclusive classrooms by teachers enrolled in a pre-service curriculum in a large Australian university. Their review of extant research as well as their own findings led them to conclude that pre-service teachers tend to over rely on paraprofessional support and, in general, require greater exposure to elements of inclusive pedagogy in their pre-service preparation. Further, they suggested greater exposure to students requiring extra-ordinary supports and services through a course-linked practicum experience in inclusive schools.

Leko and Roberts (2014) provided a review of the professional development (PD) literature examining specific implications for teaching in inclusive schools. Previous research led to the conclusion that "one shot” workshops and professional conference sessions are ineffective (Garet, Porter, Desimone, Birman, \& Yoon, 2001; Pugach, Blanton, Correa, McLeskey, \& Langley, 2009), so the question has become, what PD methods can be attributed to measurable changes in teaching performance leading to measurable changes in pupil academic gains? They concluded that an approach emphasizing an initial needs assessment followed by up-front seminars or workshops geared to specific needs assessment elements could serve as initial components in a comprehensive PD plan. Teachers would then attend follow up sessions with two-way discourse opportunities focused on analysis of student data and collaborative planning. These meetings would, in turn, be followed up with long-term support from in- 
classroom coaching and/or modeling of practices from teacher-mentors, content area coaches or others with experience and expertise in the innovative practice areas. The comprehensive model would further require observation and assessment of teacher practices to determine whether additional PD directed to elements of initial needs assessment is warranted. What was clear from their findings, is that inclusive education requires a comprehensive and ongoing professional learning agenda and long range plan. It involves different skill sets and content knowledge than required in more typical grade level and content area classrooms that do not contain students with extraordinary support needs.

Robinson, Hohepa, and Lloyd (2009) reported research validating that promotion by leadership of teacher PD produced large effects on student academic gains. Leko and Roberts (2014) recommended that school administrators and academic coaches attend all professional learning sessions as well as teacher collaborative planning sessions. They suggested that a tradeoff for time might include rearranging master schedules, reducing paperwork demands, particularly for special educators, and securing substitute teachers.

The question of location of teacher pre-service preparation programs continues to be contested terrain (Sindelar, Adams, \& Leko, 2014). Sindelar, Daunie, and Rumells (2004) reported a study that suggested school administrators were more favorably disposed to teachers trained in school district-sponsored, alternative programs than to those prepared in universitybased schools of education. Sindelar et al. (2014) cited the works of Florian (2014), writing from an international perspective, with an inclusion concept in which all teachers need to be prepared to work with all students. She argued that special education and general education, having divorced during the age of specialization, need to re-marry (my words). I am in full agreement with her premise. A need for highly specialized services and supports for students 
with such low-incidence issues as blindness, deaf/blindness, deafness, autism, etc., will always exist; but universal design for learning (UDL) practices (CAST, 2016) can be taught to general educators; and some teachers, through further education, can attain certification to become specialists. Just as we do not need to congregate people with common learning support needs in separate classes, schools, etc., we also do not need to perpetuate a separate system of teachers to address their needs.

That said, special education is likely to continue to play an important, but slightly different, role in public education, at least in the U.S. In the near term, to prepare a teaching workforce for equity-based, whole-school, inclusive education models, contemporary research such as that reported by Sindelar et al. (2014) would suggest that two immediate, workable shifts in thinking are required. First, teacher preparation should be fully integrated, and licensing programs should undergo consolidation of formerly separate, specialized teacher licenses particularly in the elementary grades. In the U.S. this shift means, to a large extent, merging general and special education pre-service personnel preparation programs for both teachers and school district administrators. Secondly, pre-service programs should be largely relocated outside of university classrooms and, through partnerships with school districts, inside schools and classrooms by offering full practicum experiences geared to pedagogical instruction within inclusive schools.

Brownell, Sindelar, Kiely, and Danielson (2010) provided a framework for pre-service teacher preparation that fulfills this prescription and offers a reconceptualization of special education. Their framework builds on the earlier recommendations of McClesky and Waldron (2002), who argued for moving away from models of transporting special education into general 
education classrooms and, instead, that we "reinvent instruction in the general education classroom based on the best methods available in both general and special education” (p. 52).

To their suggestions, I would add the admonition to move away from the grade level or content area classroom as the unit of analysis for equity-based inclusion and toward a wholeschool approach (Sailor, 2009; Booth \& Ainscow, 2011; Sailor \& Burrello, 2013). The advent of MTSS provides the beginnings of a useful school organizational framework that enables all students to be instructed in non-segregated arrangements through scheduling and skillful deployment of teaching and support personnel (Giangreco, 2013). Students with extensive support needs can be successfully included through MTSS-driven, evidence-based school-wide models where UDL practices are in place at all three tiers of academic, social, and behavioral instruction (Nelson, 2014; www.swiftschools.org)

\section{Implications for Paraprofessionals and Teaching Assistants}

Most placement-based models of inclusive education have relied heavily on the use of paraprofessionals, leading some to conclude, correctly I think, that inclusion has been steadily trending toward a paraprofessional movement that perpetuates special education as segregated service delivery in the general education classroom (Tews \& Lupart, 2008; Whitburn, 2013).

Michael Giangreco at the University of Vermont has contributed a sizeable body of research spanning over a decade, directed to offering alternatives to what has been termed the "Velcro-aide" model of including students with extensive support needs (see Giangreco, 2013 for a review of this research). In the "Velcro" model, a paraprofessional is assigned, through special education funding and supervision, to a student who usually sits at the back of the classroom with his or her aide. This approach is: (a) disruptive to the rest of the class; (b) usually disconnected to the general education curriculum in the class; (c) socially detrimental 
and stigmatizing to the student, since the aide is likely to get in the way of naturally occurring interactions among peers; and (d) turns over educational responsibility, for the most part, to unqualified personnel.

Giangreco, Suter, and Hurley (2011) set forth a structural deployment model of paraprofessionals for whole-school, inclusive practices that is a good fit, in my opinion, with a human-capabilities, school-reform approach to equity-based inclusion. Paraprofessionals in this approach in the U.S. are assigned to grade-level and/or content area classrooms, not to individual students. They are jointly supervised and evaluated by both general education and special education teachers regardless of whether they are funded from special education budgets. Their presence in the classroom is never stigmatizing to individual students identified for special education services and supports. They are never the instructor of record for any student, and they support students to be as fully integrated and interactive with their peers as possible.

\section{Instructional Innovations}

The advent of MTSS as a driver for whole-school inclusive educational praxis requires a different conceptualization of the uses of space in schools and of engagement and deployment of personnel in the instructional delivery system (Sailor, 2009; 2015). Classroom-based instructional models, even with UDL practices, pose major problems for the range and types of differentiated instruction needed to efficiently and effectively address the teaching/learning process with all students. SWIFT Center technical assistance process asks participating schools’ leadership teams to undergo two planning exercises at the outset of their installation of MTSS. First they are asked to contemplate the layout of their available spaces under current master scheduling and decide whether they are utilizing space in the most efficient way in order to fully 
implement MTSS for academic, behavioral, and social outcomes. This exercise frequently leads to new space configurations for three tiers of interventions.

The second exercise is to have the leadership team contemplate the use of all school personnel as potential agents of instruction. This exercise often results in the discovery that various school staff members have hidden talents that can be brought to bear in different aspects of delivering the overall curriculum. Custodians (or janitors), for example, may be skilled vocational educators; librarians often can lead Tier 2 reading groups; speech therapists with artistic talent could volunteer to teach an art class where the program had formerly been cut out due to budget constraints; cafeteria servers might teach students to make healthy food selection choices. All these scenarios are recent examples from SWIFT Center partner schools. Furthermore, regardless who the students and teaching adults are, MTSS employs evidencebased academic and behavior instruction. Next I discuss some recent research on emerging instructional practices that enhance whole-school, MTSS applications.

Co-Teaching. One innovative instructional delivery practice that is generating substantial interest as well as some controversy is collaborative teaching, usually between special and general educators (Murawski \& Goodwin, 2014; Saloviita, \& Takala, 2010; Solis, Vaughn, Swanson, \& McCulley, 2012). Clearly, bringing special educators into general education classrooms in collaborative teaching arrangements would be expected to enhance educational outcomes for all students, but the practice is more complicated than might be naively assumed (Ashton, 2014).

Murawski and Goodwin (2014) summarized the extant research on outcomes associated with co-teaching models as lacking clarity and consistency and with contradictory findings. Two facets of co-teaching models that emerge as problematic are (a) lack of adequate planning time, 
and (b) questionable compatibility of the personalities involved. Forced partnerships as an outgrowth of changing school organizational policy are unlikely to yield good results (Magiera \& Zigmond, 2005). The best research summaries of the emerging practice of co-teaching to date suggest that it is a promising practice that requires more research on its various models to be routinely moved into inclusive instructional practices. Further, it seems that teachers should be given the leeway to self-select into collaborative teaching arrangements rather than have such experiences arranged for them by school leadership. Adequate planning time needs to be built into teaching schedules and pre-service personnel preparation programs need to build collaborative teaching opportunities into practicum arrangements whenever possible.

Embedded Instruction. Jimenez and Kamei (2015) provide a review of the research literature on embedded instruction as applied to students with "intellectual disabilities" in inclusive settings. Embedded instruction is the practice of distributing instructional trials throughout the day in various settings, across people, places and materials in order to promote generalization of learned, discrete skills (McDonnell, Johnson, \& McQuivey, 2008). The practice appears to hold promise for whole-school, MTSS-driven inclusive schools by virtue of fitting with UDL pedagogy, applicable to all students, but in this case applied to students with cognitive learning issues.

Peer-Assisted Instruction. Various peer-assisted instructional arrangements have been reported to have successful outcomes when applied particularly to students with extensive support needs in inclusive settings (Ryndak, Jackson, \& White, 2013). Carter et al. (2016) reported results of a randomized, controlled experimental investigation of peer-assisted arrangements on academic and social outcomes with 51 students with extensive support needs in high school inclusive classrooms. The study reported increased interactions with peers, 
increased academic engagement, increased progress on social goals and social participation and increases in forming new friendships. The authors suggested that peer-assisted arrangements in inclusive schools may offer an alternative to reliance on individually-applied paraprofessional support models.

\section{Whole-School Inclusive Educational Arrangements}

In my opinion, we no longer need to address the question, "should we include students with extra-ordinary needs for support and services in the general education program?” The preponderance of available research supports inclusive education. The question is how best to deliver the goods? I argue that a placement-based definition of inclusion grounded in the medical model construct of disability and its various categories will not get us to the promised land. What is needed is a reframing of the whole project of public education addressed to a broader question of how best to distribute and apply all available resources through matching evidence-based instructional practices to measured student need (i.e., MTSS).

Batsche (2014) provided an excellent delineation of the parameters of MTSS as these are generally understood at present. He listed the critical elements as:

1. All instruction is evidence-based, aligned with common standards, and delivered in varying levels of intensity (tiers).

2. Instructional planning involves all instructional providers working collaboratively to align instructional focus and pacing.

3. The roles and responsibilities of all staff delivering instruction are understood, aligned, and add value to student outcomes. 
4. Common assessments are used to evaluate the impact of the multi-tiered system of supports on student growth. Assessments are aligned with the common standards.

5. The multi-tiered instruction and supports are integrated across tiers to ensure that all instruction is related and relevant.

6. Instructional strategies and student engagement variables and the relationship between the two are considered when instruction is designed and delivered by all providers.

7. Students and families are informed partners in understanding, supporting, and engaging the instruction.

Literacy Outcomes. Harn, Fritz, and Berg (2014) provided a review of research on MTSS applications to literacy instruction in inclusive schools. They concluded that MTSS allow schools the opportunity to more effectively meet the literacy goals of a wider range of students including those with extraordinary support needs.

Data-based Decision Making. Movement within and across tiers of intensity in MTSS depends upon reliable and valid measures of pupil performance at frequent intervals, that is, progress monitoring. Wakeman, Browder, and Flowers (2011) reviewed the application of emerging alternate assessments geared to alternate achievement standards and curriculum-based measures (CBM) as critical tools in assisting teaching teams as well as individual teachers to make timely decisions concerning movement of students with additional needs for academic support within and across the tiers of instructional intensity.

School Team Configurations. The term “adhocracy” has been applied to descriptions of organizational arrangements characterized by democratic decision processes as opposed to top 
down "bureaucratic" decision models (cf., Skrtic, 1993). Collaborative teaming arrangements in whole-school, equity-based applications of inclusive schooling afford the opportunities for discursive problem solving necessary to engineer successful applications of fully integrated inclusive schools. Ryndak, Lehr, Ward, and DeBevoise (2014) provided a review of successful teaming arrangements in inclusive settings. Hunt, Soto, Maier, and Doering (2003) similarly reviewed successful teaming arrangements directed to ensuring that students with the most extensive support needs could achieve successful outcomes in inclusive schools. What is clear from all sources on team planning arrangements is that team building practices need to be incorporated into pre-service personnel preparation programs. Team planning is essential to the adhocratic, problem-solving discourses necessary to guide successful applications of wholeschool MTSS. All meetings need to start and end on schedule, have an agenda, report out all decisions to the school community of practice, and most importantly, be time-managed for efficiency.

\section{Conclusion and Summary}

Inclusion, as it is typically advanced in educational policy and practice, poses a wicked problem. From a global perspective, the Salamanco Conference (UNESCO, 1994) advanced the human rights agenda by calling for education of all children together. In the U.S., efforts to advance inclusion have come through litigation associated with the Individuals with Disabilities Education Act (IDEA), the former Education of the Handicapped Amendments (EHA-1974). Several Supreme Court decisions have affirmed the rights of students to be educated in the least restrictive environment (LRE). Further, federal policy initiatives since the 1980s have attempted to increase inclusive opportunities for students with extensive support needs (Sailor \& Burrello, 2013). Finally, a preponderance of rigorous research found better academic and social outcomes 
for students receiving special education services and supports in inclusive settings. Yet, despite these three fronts of activity, inclusion remains elusive, particularly for students with more extensive needs for services and support.

I argue in this paper that the problem is un-solvable because of the way the problem is framed within the greater context of education. Globally, the prevalent model for addressing learning challenges has been quasi-medical, simply locating the problem as a characteristic of the individual rather than one of interplay between student issues and the learning ecology. We have framed the problem as “disability” rather than a more pragmatic frame of identifying resources, and evidence-based supports and services to address any and all challenges in the teaching/learning process. Ainscow $(1991 ; 2014)$ has been advancing a similar positon for two and a half decades, as have others, but the medical model frame in education of disability and other categorical marginalizing influences (e.g., “gifted”, “economically disadvantaged”, “language learners”) keep moving the policy discourse toward a conundrum of tensions that reflect the intersection of the social justice principles of inclusion, where education is a human right of intrinsic value, and education reform policies that are based on the principles of the marketplace, where education is a means to other ends such as individualism and economic competitiveness (Florian \& Rouse, 2014, p. 510).

Reframing the education project as an equity issue, wherein the distribution of resources generated through rigorous research becomes available to all students on the basis of measured need for assistance, allows us to move away from the medical model. Instead, we recast “special” education as a set of particular evidence-based resources directed to specialized applications for learning issues related to physical, social/behavioral, perceptual, or cognitive characteristics of individual students, including combinations of any of the above challenges. 
Further, it enables us to replace the "disability” construct with a human capabilities framework that seeks to build on individual strengths rather than focus on limiting issues (Burrello et al., 2013).

Finally, I argue that the advent of MTSS, whole-school rather than classroom-focused applications of instruction, UDL, and fully integrated teacher preparation and licensing programs enable the reframing project to emerge with successful models of application in practice (Sailor, 2014). Halle and Dymond (2008-09) set the tone for transformational discourse on schooling with this thought: "rather than striving for 'sameness' by limiting instructional contexts to general education classrooms, ... expand educational contexts for all learners to incorporate inclusive settings outside the classroom and in the community” (p.197).

\section{References}

Ainscow, M. (2014). From special education to effective schools for all: Widening the agenda. In L. Florian (Ed.), The Sage Handbook of Special Education (2nd Edition), London: Sage.

Ainscow, M., \& Cesar, M. (2006). Inclusive education ten years after Salamanca: Setting the agenda. European Journal of Psychology and Education, 21, 231-238. doi:10.1007/BF03173412

Ainscow, M. (1991). Effective schools for all. London: David Fulton.

Apple, M. (2006). Educating the "right” way: Markets, standards, god, and inequality. New York: Taylor \& Francis.

Artiles, A., \& Kozleski, E. (2016). Inclusion’s promises and trajectories. Critical notes about future research on a venerable idea. Education Policy Analysis Archives, 24. doi:10.14507/eppaa.24.1919 
Artiles, A., \& Kozleski, E. (2007). Beyond convictions: Interrogating culture, history, and power in inclusive education. Language Arts, 84(4), 357-364.

Ashton, J. R. (2014). Beneath the veneer: Marginalization and exclusion in an inclusive coteaching context. International Journal of Whole Schooling, 10(1), 43-62.

Barton, L. (Ed.). (1987). The politics of special education needs. Lewes, UK: Falmer Press.

Batsche, G. (2014). Multi-tiered system of supports for inclusive schools. In J. McLeskey, N. L. Waldron, F. Spooner, \& B. Algozzine (Eds.) Handbook of effective inclusive schools (pp. 183-196), New York: Routledge.

Bogdan, R., \& Kugelmass, J. (1984). Case studies of mainstreaming: A symbolic interactionist approach to special schooling. In L. Barton \& S. Tomlinson (Eds.), Special education and social interests (pp. 173-191). London: Broom-Helm.

Bolman, L.E., \& Deal, T.E. (2013). Reframing organizations (5th Edition). San Francisco: Jossey-Bass.

Booth, T., \& Ainscow, M. (2011). Index for inclusion: Developing learning and participation in schools. Bristol, U.K.: Centre for Studies on Inclusive Education.

Brock, M. E., \& Schaefer, J. M. (2015). Location matters: Geographic location and educational placement of students with developmental disabilities. Research and Practice for Persons with Severe Disabilities, 40, 154-164. doi:10.1177/1540796915591988

Browder, D., Hudson, M. E., \& Wood, L. (2014). Using principles of high quality instruction in the general education classroom to provide access to the general education curriculum. In J. McLeskey, N. L. Waldron, F. Spooner, \& B. Algozzine (Eds.). Handbook of effective inclusive schools (pp. 30-42). New York: Routledge. 
Brown, L., Shiraga, B., \& Kessler, K. (2006). The quest for ordinary lives: The integrated postschool vocational functioning of 50 workers with significant disabilities. Research and Practice for Persons with severe Disabilities, 31, 93-121. doi:10.1177/154079690603100202

Brownell, M. T., Sindelar, P. T., Kiely, M. T., \& Danielson, L. C. (2010). Special education teacher quality and preparation: Exposing foundations, constructing a new model. Exceptional Children, 76, 357-377. doi: 10.1207/s15327035ex1204_3

Burrello, L.C., Sailor, W., \& Kleinhammer-Tramill, J. (2013). Unifying educational systems. New York: Routledge.

Carter, E. W., Asmus, J., Moss, C. K., ... \& Weir, K. (2016). randomized evaluation of peer support arrangements to support the inclusion of high school students with severe disabilities. Exceptional Children, 82, 209-233. doi: 10.1177/0014402915598780

CAST. (2016). About Universal Design for Learning [website]. Available at http://www.cast.org/our-work/about-udl.html\#.Vst9bhhW6wY

Causton, J. \& Theoharis, G. (2014). How do schools become effective and inclusive? In J. McLeskey, N. L. Waldron, F. Spooner, \& B. Algozzine (Eds.). Handbook of effective inclusive schools (pp. 30-42). New York: Routledge

Courtade, G., Jimenez, B., \& Delano, M. (2014). Providing effective instruction in core content areas (literacy, mathematics, science, and social studies) in inclusive schools. In J. McLeskey, N. L. Waldron, F. Spooner, \& B. Algozzine (Eds.). Handbook of effective inclusive schools (pp. 30-42). New York: Routledge

Deal, T. E., \& Peterson, K. D. (2009). Shaping school culture (2nd Edition). San Francisco: Jossey-Bass. 
Dempsey, I. (2012). The use of individual education programs for children in Australian schools. Australasian Journal of Special Education, 36, 21-31. doi: 10.1017/jse.2012.5

Di Paola, M., Tschannen-Moran, M., \& Walther-Thomas, C. (2004). School principals and special education: Creating the context for academic success. Focus on Exceptional Children, 37(1), 1-10.

Di Paola, M. F., \& Walther-Thomas, C. (2003). Principals and special education: The critical role of school leaders (COPSSE Document No. IB-7E). Gainesville, FL: University of Florida, Center on Personnel Studies in Special Education.

Farrell, P., Dyson, A., Polat, F., Hutcheson, G., \& Gallannaugh, F. (2007). Inclusion and achievement in mainstream schools. European Journal of Special Needs Education, 22, 131-145. doi: 10.1080/08856250701267808

Feldman, R., Carter, E. W., Asmus, J., \& Brock, M. E. (2015). Presence, proximity, and peer interactions of adolescents with severe disabilities in general education classrooms. Exceptional Children, 82, 192-208. doi: 10.1177/0014402915585481

Florian, L. (2014). Preparing teachers to work with students with disabilities: An international perspective. In P. T. Sindelar, E. D. McCray, M. T. Brownell, \& B. Lignugaris-Kraft (Eds.), Handbook of research on special education teacher preparation. (pp. 47-64) New York: Routledge.

Florian, L., \& Rouse, M. (2014). International perspectives: What can be known about effective inclusive schools? In J. McLeskey, N. L. Waldron, F. Spooner, \& B. Algozzine (Eds.). Handbook of effective inclusive schools (pp. 507-520). New York: Routledge

Fox, N. \& Ysseldyke, J. (1997). Implementing inclusion at the middle school level: lessons from a negative example, Exceptional Children, 64(1), 81-98. 
Fuchs, L. S., Fuchs, D., Compton, D. L., ... \& Jordan, N. C. (2014). Inclusion versus specialized intervention for very-low-performing students: What does access mean in an era of academic challenge? Exceptional Children, 81(2), 131-157.

Fullan, M. (2004). Leadership and sustainability: System thinkers in action. Thousand Oaks, CA: Corwin Press.

Garet, M. S., Porter, A. C., Desimone, L., Birman, B. F., \& Yoon, K. S. (2001). What makes professional development effective? Results from a national sample of teachers. American Educational Research Journal, 38, 915-945. doi:10.3102/00028312038004915.

Giangreco, M. F. (2013). Teacher assistant supports in inclusive schools: Research, practices and alternatives. Australasian Journal of Special Education, 37, 93-106. doi:10.1017/jse.2013.1

Giangreco, M. F., \& Suter, J. S. (2015). Precarious or purposeful? Proactively building inclusive special education service delivery on solid ground. Inclusion, 3, 112-131. doi:10.1352/2326-6988-3.3.112

Giangreco, M. F., Suter, J. S., Hurley, S. M. (2011). Revisiting personnel utilization in inclusionoriented schools. Journal of Special Education, 47, 121-132. doi:10.1177/0022466911419015.

Grima-Farrell, C. R., Bain, A., \& McDonagh, S. H. (2011). Bridging the research-to-practice gap: A review of the literature focusing on inclusive education. Australasian Journal of Special Education, 35, 117-136. doi:10.1375/ajse.35.2.117

Hall, S. \& Jacques, M. (Eds.). (1989). New times: the changing face of politics in the 1990 s. London: Lawrence and Wishart. 
Halle, J. W., \& Dymond, S. K. (2008-09). Inclusive education: A necessary prerequisite to accessing the general curriculum? Research \& Practice for Persons with Severe Disabilities, 33-4, 196-198.

Harn, B., Fritz, R., \& Berg, T. (2014). Effective literacy instruction in inclusive schools. In J. McLeskey, N. L. Waldron, F. Spooner, \& B. Algozzine (Eds.) Handbook of effective inclusive schools (pp. 229-246). New York: Routledge.

Hemmings, B., \& Woodcock, S. (2011). Preservice teachers’ views of inclusive education: A content analysis. Australasian Journal of Special Education, 35, 103-116.

doi:10.1375/ajse.35.2.103

Hunt, P., Soto, G., Maier, J., \& Doering, K. (2013). Collaborative teaming to support students at risk and students with severe disabilities in general education classrooms. Exceptional Children, 69, 315-332. doi:10.1177/001440290306900304

Jackson, L. B., Ryndak, D. L., \& Wehmeyer, M. L. (2010). The dynamic relationship between context, curriculum, and student learning: A case for inclusive education as a researchbased practice. Research and Practice for Persons with Severe Disabilities, 34, 175-195. doi:10.2511/rpsd.33.4.175

Jimenez, B. A., \& Kamei, A. (2015). Embedded instruction: An evaluation of evidence to inform inclusive practice. Inclusion, 3, 132-144. doi:10.1352/2326-6988-3.3.132

Kauffman, J. M. \& Hallahan, D. P. (Eds.). (1995). The illusion of full inclusion: a comprehensive critique of a current special education bandwagon. Austin, TX: Pro-ed.

Kauffman, J. M., McGee, K., \& Brigham, M. (2004). Enabling or disabling? Observations on changes in special education. Phi Delta Kappan, 85, 613-620. 
Kleinert, H., Towles-Reeves, E., Quenemoen, R., ... \& Kerbel, A. (2015). Where students with the most significant cognitive disabilities are taught: Implications for general curriculum access. Exceptional Children, 81, 312-328. doi: 10.1177/0014402914563697

Kleinhammer-Tramill, J., Burrello, L.C., \& Sailor, W. (2013). Special education: A critical perspective on reframing public policy for students with disabilities. In L. C. Burrello, W. Sailor, \& J. Kleinhammer-Tramill (Eds.), Unifying educational systems (pp. 3-20). New York: Routledge.

Klingner, J. D., Arguelles, M. E., Hughes, M. T., \& Vaughn, S. (2001). Examining the schoolwide “spread” of research-based practices. Learning Disability Quarterly, 24, 221-234. doi:10.2307/1511112

Knight, J. (2007). Instructional coaching. Thousand Oaks, CA: Corwin Press.

Kozleski, E. \& Siuty, M. B. (2016). The complexities of inclusive education: How cultural histories shape the ways teachers respond to multiple forms of diversity. Downloaded February 11, 2015 from http://capacitybuildingnetwork.org/article6/

Kuhn, T.S. (1970). The structure of scientific revolutions ( $2^{\text {nd }}$ ed.). Chicago: University of Chicago Press.

Kurth, J. A., Morningstar, M. E., \& Kozleski, E. B. (2014). The persistence of highly restrictive special education placements for students with low-incidence disabilities. Research and Practice for Persons with Severe Disabilities, 39, 227-239. doi:10.1177/1540796914555580

Leko, M. M., \& Roberts, C. A. (2014). How does professional development improve teacher practice in inclusive schools? In J. McLeskey, N. L. Waldron, F. Spooner, \& B. 
Algozzine (Eds.), Handbook of effective inclusive schools (pp. 43-54). New York: Routledge.

Lewis, A., \& Norwich, B. (2005). Special teaching for special children? Milton Keynes: Open University Press.

Lyons, G. \& Cassebohm, M. (2012). The education of Australian school students with the most severe intellectual disabilities: Where have we been and where could we go? A discussion primer. Australasian Journal of Special Education, 36, 79-95. doi:10.1017/jse.2012.8

Magiera, K. \& Zigmond, N. (2005). Co-teaching in middle school classrooms under routine conditions: Does the instructional experience differ for students with disabilities in cotaught and solo-taught classes. Learning Disabilities Research and Practice, 20, 79-85. doi: 10.1111/j.1540-5826.2005.00123.x

McDonnell, J., Johnson, J.W., \& McQuivey, C. (2008). Embedded instruction for students with developmental disabilities in general education classrooms. Arlington, VA: Council for Exceptional Children.

McDonnell, J., Thorson, N., Disher, S., Mathot-Buckner, C., Mendel, J., \& Ray, L. (2003). The achievement of students with developmental disabilities and their peers without disabilities in inclusive settings: An exploratory study. Education and Treatment of Children, 26(3), 224-236.

McKnight, John (1995). The careless society. New York: Basic Books.

McLaughlin, T. W., Snyder, P. A., \& Algina, J. (2015). Characterizing early childhood disabilities in a nationally representative sample using functional profiles. Exceptional Children, 81, 471-488. doi: 10.1177/0014402914563696 
McLeskey, J., Landers, E., Williamson, P., \& Hoppey, D. (2012). Are we moving toward educating students with disabilities in less restrictive settings? The Journal of Special Education 46, 131-140. doi:10.1177/0022466910376670

McLeskey, J. \& Waldron, N. L. (2002). Professional development and inclusive schools: Reflections on effective practice. The Teacher Educator, 37, 159-172. doi:10.1080/08878730209555291.

McLeskey, J., Waldron, N. L., Spooner, F. \& Algozzine, B. (Eds.). (2014). Handbook of effective inclusive schools. New York: Routledge.

McMaster, C. (2013). Building inclusion from the ground up: A review of whole school reculturing programmes for sustaining inclusive change. International Journal of Whole Schooling, 9(2), 1-24.

Mintz, J., \& Wyse, D. (2015). Inclusive pedagogy and knowledge in special education: addressing the tension. International Journal of Inclusive Education, 19, 1161-1171. doi:10.1080/13603116.2015.1044203

Morris, C. \& Sharma, U. (2011). Facilitating the inclusion of children with vision impairment: Perspectives of itinerant support teachers. Australasian Journal of Special Education, 35, 191-203. doi:10.1375/ajse.35.2.191

Murawski, W. W., \& Goodwin, V. A. (2014). Effective inclusive schools and the co-teaching conundrum. In J. McLeskey, N. L. Waldron, F. Spooner, \& B. Algozzine (Eds.) Handbook of effective inclusive schools (pp. 292-305). New York: Routledge. National Center for Systemic Improvement. (2013). Website. https://www.wested.org/project/national-center-for-systemic-improvement/ 
Nota, L., Soresi, S., \& Ferrari, L. (2014). What are emerging trends and perspectives on inclusive schools in Italy? In J. McLeskey, N. L. Waldron, F. Spooner, \& B. Algozzine (Eds.). Handbook of effective inclusive schools (pp. 30-42). New York: Routledge.

Oh-Young, C. \& Filler, J. (2015). A meta-analysis of the effects of placement on academic and social skill outcome measures. Research in Developmental Disabilities 47, 80-92. doi:10.1016/j.ridd.2015.08.014

Peetsma, T., Vergeer, M. Roeleveld, J., \& Karsten, S. (2001). Inclusion in education: Comparing pupils’ development in special and regular education. Educational Review, 53, 125-135. doi:10.1080/00131910125044

Pugach, M. C., Blanton, L. P., Correa, V. I., McLeskey, J., \& Langley, L. K. (2009). The role of collaboration in supporting the indication and retention of new special education teachers. (NCIPP Doc. No. RS-2). Retrieved July 28, 2013, from University of Florida, National Center to Inform Policy and Practice in Special Education Professional Development Website: http://www.ncipp.org/reports/rs_2.pdf

Rittel, H. W. J., \& Weber, M. M. (1973). Dilemmas in a general theory of planning. Policy Sciences, 4(2), 155-169. doi:10.1007/BF01405730

Robinson, V., Hohepa, M., \& Lloyd, C. (2009). School leadership and student outcomes: Identifying what works and why. Wellington, New Zealand: Ministry of Education. Rorty, R. (1989). Contingency, irony, and solidarity. New York: McGraw-Hill.

Ryndak, D. L., Jackson, L. B., \& White, J. M. (2013). Involvement and progress in the general curriculum for students with extensive support needs: K-12 inclusive-education research and implications for the future. Inclusion, 1, 28-49. doi:10.1177/0741932514555021. 
Ryndak, D., Lehr, D., Ward, T., \& DeBevoise, H. (2014). Collaboration and teaming in effective inclusive schools. In J. McLeskey, N. L. Waldron, F. Spooner, \& B. Algozzine (Eds.) Handbook of effective inclusive schools (pp. 395-409). New York: Routledge.

Sailor, W. (2015). Advances in schoolwide inclusive school reform. Remedial and Special Education, 36, 94-99. doi: 10.1177/0741932514555021

Sailor, W. (2009). Making RTI work. How smart schools are reforming education through schoolwide RTI. New York: Jossey-Bass.

Sailor, W. \& Burrello, L. C. (2013). Shifting perspective to frame disability policy. In L. C. Burrello, W. Sailor, \& J. Kleinhammer-Tramill (Eds.), Unifying educational systems (pp. 21-40), New York: Routledge.

Sailor, W. \& McCart, A. B. (2014). Stars in alignment. Research and Practice for Persons with Severe Disabilities, 39, 55-64. doi: 10.1177/1540796914534622

Sailor, W., \& Paul, J. L. (2004). Framing positive behavior support in the ongoing discourse concerning the politics of knowledge. Journal of Positive Behavior Interventions, 6, 3749. doi:10.1177/10983007040060010601

Saloviita, T. \& Takala, M. (2010). Frequency of co-teaching in different teacher categories. European Journal of Special Needs, 25, 289-396. doi: 10.1080/08856257.2010.513546

Schoolwide Integrated Framework for Transformation Center, National Technical Assistance Center on Inclusive School Reform. (2016). SWIFT [website]. Available at swiftschools.org.

Schön, D. A. (1984). The crisis of professional knowledge and the pursuit of an epistemology of practice (Report for the Harvard Business School). Cambridge. MA: Harvard University. 
Sindelar, P. T., Adams, A. J., \& Leko, C. D. (2014). How can teacher education improve effective inclusive schools? In J. McLeskey, N. L. Waldron, F. Spooner, \& B. Algozzine (Eds.) Handbook of effective inclusive schools (pp. 55-66). New York: Routledge.

Sindelar, P. T., Daunic, A. P., \& Rennells, M. S. (2004). Comparisons of traditionally and alternatively trained teachers. Exceptionality, 12, 209-223. doi:10.1207/s15327035ex1204_3

Skrtic, T. M. (1993). The crisis in special education knowledge: A perspective on perspective. In E. L. Meyen, G. A. Vergason, \& R. J. Whelan (Eds.), Challenges facing special education (pp. 165-192). Denver: Love Publishing Co.

Slee, R. \& Allan, J. (2001). Excluding the included: A reconsideration of inclusive education. International Studies in Sociology of Education, 11, 173-192. doi:10.1080/09620210100200073

Smith, P. (2007). Have we made any progress? Including students with intellectual disabilities in regular education classrooms. Intellectual and Developmental Disabilities, 45, 297309. doi:10.1352/0047-6765(2007)45[297:HWMAPI]2.0.CO;2

Solis, M., Vaughn, S., Swanson, E., \& McCulley, L. (2012). Collaborative models of instruction: The empirical foundations of inclusion and co-teaching. Psychology in the Schools, 49, 498-510. doi:10.1002/pits.21606

Tews, L., \& Lupart, J. (2008). Students with disabilities' perspectives of the role and impact of paraprofessionals in inclusive education settings. Journal of Policy and Practice in Intellectual Disabilities, 5, 39-46. doi:10.1111/j.1741-1130.2007.00138.x

Tschannen-Moran. (2004). Trustworthy leadership: The heart of productive schools. San Francisco: Jossey-Bass. 
United Nations General Assembly. (1994). Salamanca statement and framework for action on special needs education. Salamanca: UNESCO.

U.S. Department of Education, Office of Special Education and Rehabilitation Services. (2016).

RDA: Results Driven Accountability [website]. Available at http://www2.ed/gov/about/offices/list/osers/osep/rda/index.html

U.S. Department of Education. (2010). Elementary and secondary education: A blueprint for reform. Available at http://www2ed.gov/policy/elsec/leg/blueprint/publicationtoc.html.

Wakeman, S. Y., Browder, D., \& Flowers, C. (2011). Alternate achievement standards for alternate assessments: Considerations for policy and practice. In M. Russell (Ed.), Assessment in the margins. Charlotte, NC: Information Age.

Walton, E. (2011). Getting inclusion right in South Africa. Intervention in School and Clinic, 46(4), 240-245.

Whitburn. B. (2013). The dissection of paraprofessional support in inclusive education: 'You're in mainstream with a chaperone’. Australasian Journal of Special Education, 37, 147161. doi:10.1017/jse.2013.12 